大阪汿方大学医学部, 解剖学教室 (指導者: 鉿木 清教授).

Dept. of Anat., School of Medicine, Osaka City Univ. (Director : Prof. K. SuzukI).

\title{
豚の鼻皮飞的ける求心性神経終末.
}

\section{Afferent Nerve-Endings in the Snout-Skin of a Pig.}

\author{
今子 邦罗 Kunio IMAKO.
}

(Received July 18, 1958.)

筆者が「八ムスター鼻皮に於ける求心性神経終末」(1958)で強調したように, 神経終末の研究にあたっては，可能な限り，神経終末の先端と Erfolgsorgan の細 胞とがいかなる関係てあるかを迫求しなくてはならない。

神経終末に関する研究恃，これまで数多くなされてきているが，この点につい て満足のいく成果をあげ得た論文は少い，ただ Boekeが早くからこのことの重要

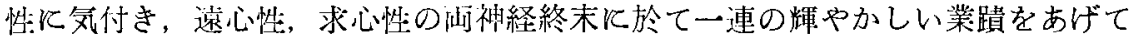
いるのみである，而し乍ら Boeke の研究に於ても，尚今後の詳細な探究にまつ未 解決の帒が多いのである。

動物の皮虞は重要な感覚器官であるが，中でわ舅部皮膚はとりわけ知覚の発達 した部位である。この場所がどのような構造をもった知覚神経終末器官によって 構成されているか，その種類と形態学とを知る為に，これまで種々な動物が研究 対象になってきた，豚の鼻皮もその5ちの1つであり，Tretjakoff (1902)，Kadanoff（1924）の報告がある。

豚の上皮細胞はハムスター，モグラなどに比べて火きく，知覚神経終末と上皮 細胞との関係を知るのに大きな利点となっている。

鍍銀法として, 在来の方法に比して全く劃期的なるのである鈴木清氐鍍銀法を もって，豚の鼻皮に扮ける知覚神経終末を研究し，これまでの絬果より，一㜿精 密な形態を明らかにし得たのでここに報告する。

\section{I. 材料 亡研究方法。}

材料としては成熟した豚の鼻皮を用いた。

今回は材料の関係上環流固定法を行わずに，屠殺後可及的速やかに豚の睤の部 行を直接 $20 \%$ Formalin 液に入れた。

約 2 週間固定した後に，鼻孔間とその下の部分を皮虞と垂直断し又水平断して 谏結法によってほぼ 30 ルの切片をつくった。又セロイヂン法による連続切片を も作成した。この切片に鈴木清氏鉸銀法を施した。鈴木清氏鍍銀法（鈴木 1958） の詳細については，ここでは省略する。

濑結切片に鈴木掯氏鍍銀法を施行した後, 標本の一部には尚 Eosin 染色, Sudan 
III 脂肪染色, Azan 染色による複染色を行った.

\section{II. 所 見.}

表皮, 真皮, 毛の順序に観察の䋨果を述べる.

\section{A. 表皮。}

豚の鼻部表皮は非常飞厚く，肧牙層，顆粘層，淡明層，角質層と明らか飞区別

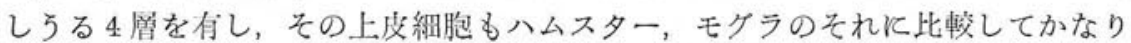
大きい.

この表皮には次の 2 程類の求心情神経終末があらわれる.

a）上皮内自由神経終末.

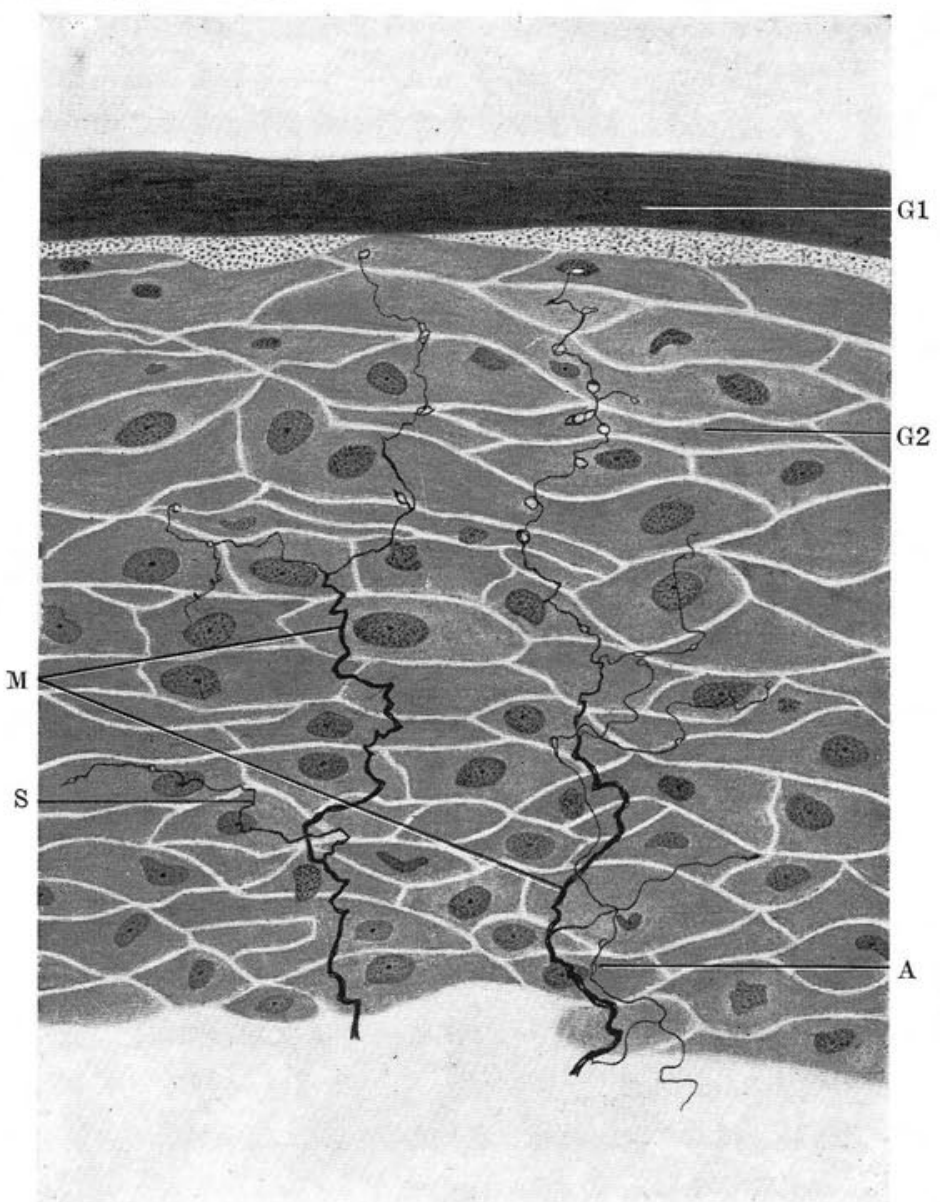

Fig. 1. Free nerve ramifications inside the epithelium with intraplasmic end-knobs and'nerve fibers in the snout-skin of a pig. $G 1$ granular layer, $G 2$ germinal layer, $M$ main (thick) nerve fibers, $A$ accessory (thin) nerve fiber, $S$ side-branch. 
この上皮内自由神経終末(四 1と2) は真皮乳䫓と乳顥の間にはさまれた 上皮 (Epithelzäpfchen) 飞於てかな り数多く認められる。乳䫓より上皮 内以俊人するものる存在する。

この上皮内自由神紸終末は更飞次 の 2 つものと分つことが出米る.

1. 主線維 (Hauptfasern).

真皮の有雨值神䋑線維束より分れた 有骮道神経は，乳頭と乳䫒とにはさま れた上皮の部分より，又若干のもの は乳頭内部を术って，それょり表皮 内部に俊人する。侵人する直前或い は侵入後. 直ち飞䯣鞘, Schwann 鞘 の雨鞘を失って全く裸の軸索のみと なる。この裸の軸索が 1 個の細胞内 部に入り，次いでその細胞を去り， 次の上皮細咆内部飞入り，かくし作 らジグザグ形をとりつつ, 次第に細 くなって肧牙層最上層飞達し, 顆歧

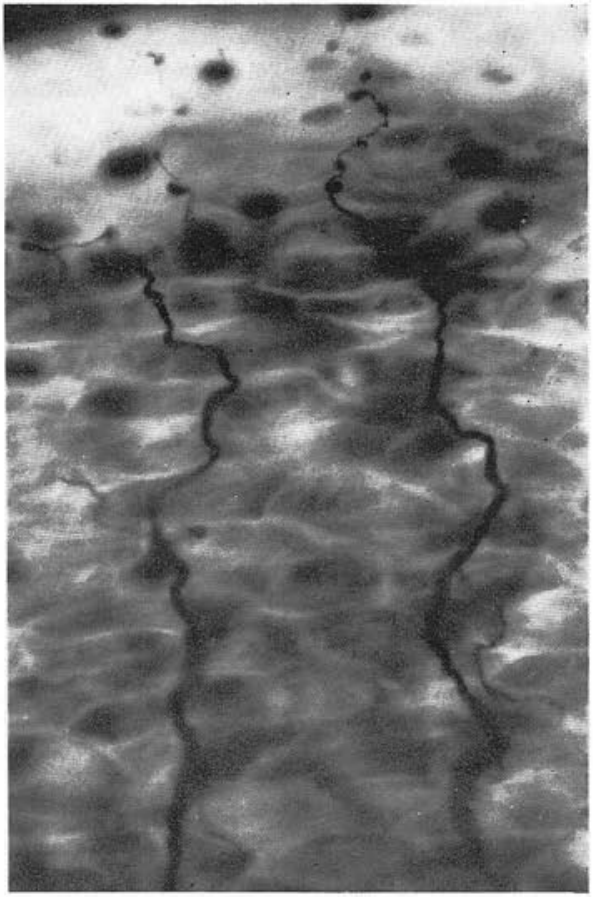

Fig. 2. Photomicrograph of Fig. 1. $\times 600$

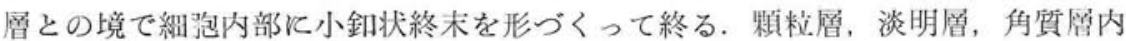
部に終るるのは熟められなかった。この小釗状㳟ふくらみは肧芽居の上層近くな

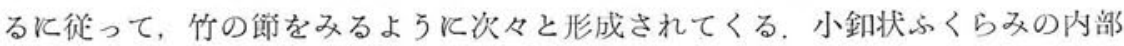
は原線維些の網状構造を呈していることはなく，却って空胞状であった，上皮内 神経はその走行の途中で側枝（Seitanästchen）を出したり，係踣 (Schlinge) を作 ったり，又二叉に分れたりする（図1，M）.

2. 副綵維 (Nebenfasern).

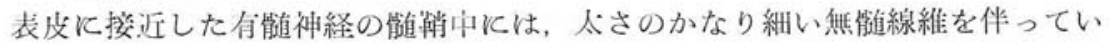
ることが多いが，この無髄線維も亦上皮内部に侵入する。即ち有䯣神経より派生 した太い主線維の周讲を丁度木に細いッタがからむように, その径の極めて細い 無䯣神経由米の副線維が走っている。主線維と副線維とはかなり近接して走って いるが，再者の接触を示すこと殆んどない，而し年ら主線維と副線維とが合流し あっているのを認めることもある、この副線維も亦主線維と同じく上皮細胞間の みならず，上皮細胞内部をも通過する(図 $1, \mathrm{~A})$.

b) 触喾細胞.

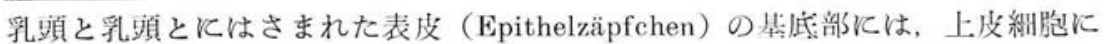
比べてかなり明るい絒胞の集団が現われる。斦淉 Merkel の触敩絒胞である。 
この Merkel の触覚細胞を多数の標本について, 又非常に精細に観察すると, これ又次の 2 型と分つことが出来る.

1. 今子-敛木の触敩細咆第 I 型（図 3 と 4). 真皮の乳頭と乳頭との間の表皮 の基底部に入った神経線維のあるるのは, 触敩細胞内部に入ってカップ型をした 神経原線維性の所謂触覚盤を形成する。この触鸴盤はかなり扁平化した触喾細胞

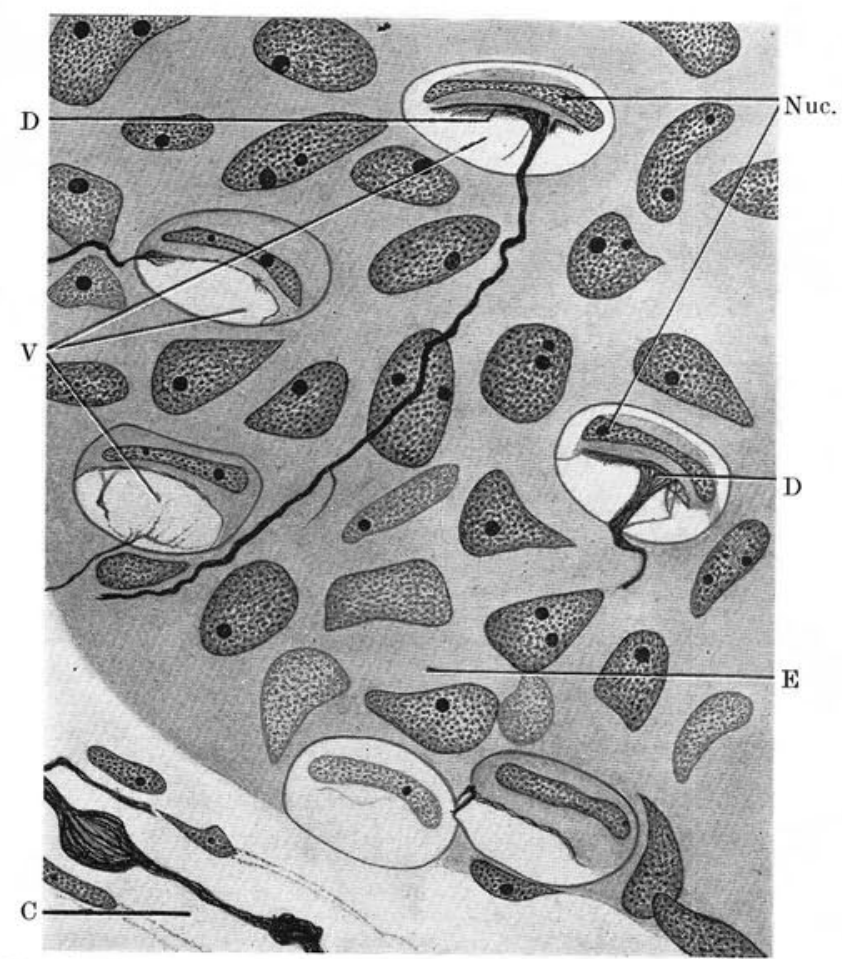

Fig. 3. The first type of tactile cell of IMAKO-SUZUKI in the epidermis of the snout-skin. Nuc. nuclei, $V$ vacuoles, $D$ tactile disc, $E$ epidermis, $C$ club-like end-bulb.

核に接してその下側, 即ち真皮に面した側につくられる。この触覚盤と接してそ の下方の原形質内部に, 触敩細胞の略々半分を占めるほどの非常に明るい空胞が 存在している．触覚盤は丁度この空胞に密着してこれを抱くような形を呈する. 触敩盤とこの空胞との関係を尚精しく観ると, 触覚盤より更に微細な神経原線維 が出てこの空胞をとり囲んでいる．触覚細胞が他の上皮細胞に比較して明るく見 えるのはこの空胞の為であり, この空胞は鍍銀法, Azan 染色, Sudan III 脂肪染 色, Eosin 単染色飞よって子染らない.

触覚細胞は Epithelzäpfchen 基底部に集団的に存在しているが, 触敩細胞への神 経支配の状態をみると, 上皮内に入った神経線維から若干の枝が出て, その枝の

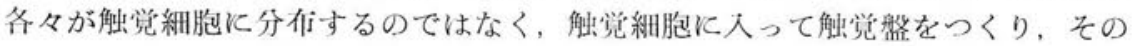


触敩盤から吏に枝が出て, 他の触 営細胞に入って触敩盤をつくり, それから又他の触觉細胞にいくの である。即ち数珠つなぎ形式をと っている(図5).

2. 今子-鈴木の触喾 細胞第 II 型（四6 6 と 7 ).

上述した第 I 型が Epithelzäpfchen の基底部に於ける触覚細胞 の人多数を占めているが, 多数の 槽本について尚入念な観察を続け ていくと，同じく基底部に神経支 配の形式が第 I 型とは明らかに異 った細胞が存在している. 今仮に これを今子-鈴木の触鸴細胞第 II 型と名づける。

紏胞内部火入った神経線維が触 敩盤をつくらず,この神経線維か ら出た微細な神経原線維性の網目 が核をとりまいている形である.

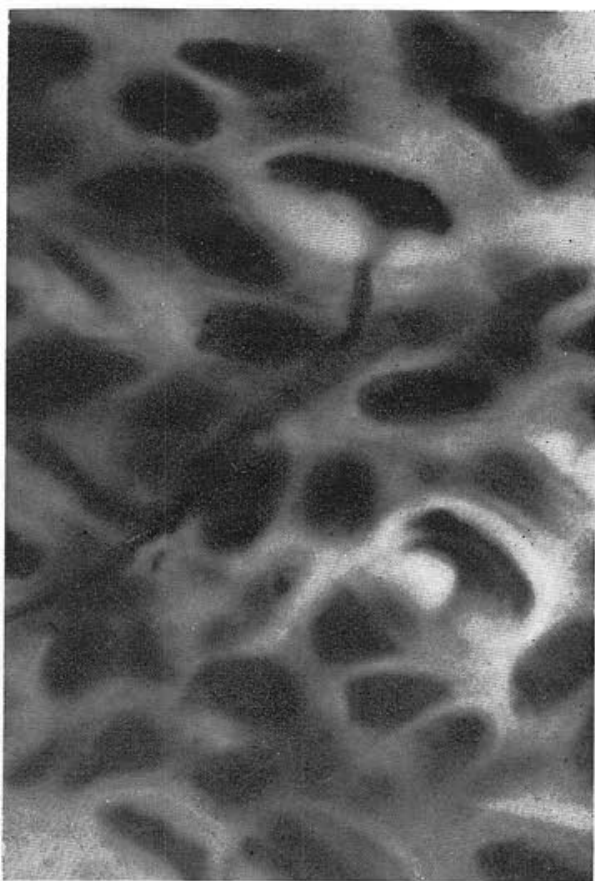

Fig. 4. Photomicrograph of Fig. 3. $\times 2,000$

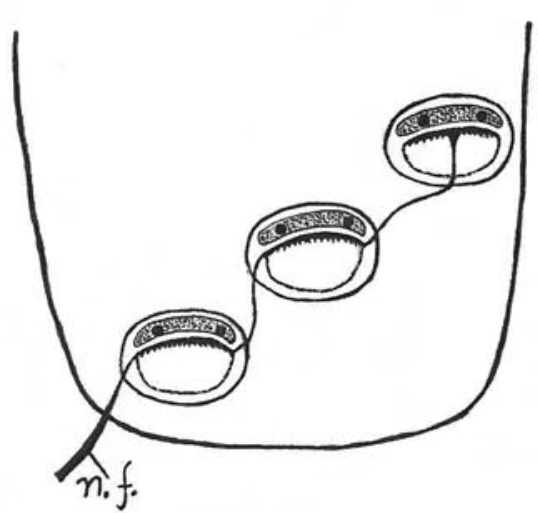

Fig. 5. Diagram illustrating the innervation-mode of the first type of tactile cell of IMAKO-SUZUKI. $n$. $f$. nerve fiber.
この細胞には空胞はなく，その核は比 較的円く大きい、筆者の観察では,こ の細胞は空胞をもった上述第 I 型より 数に於て滛かに少い。この第II型の神 経支配の柡式も，上皮内の1本の神経 線維から $2-3$ の枝が出て, その各々 が触觉細胞に終っているのではなく， 第 I 型と同じく数珠つなぎ形式であ る.

触営細胞から更飞上皮内自由神経終 末となって終るもの, 又上皮内自由神 経終末の分枝が触覚盤をつくって終る ような神経線維は認められない。

上の如く触党細咆を第 I 型と第II型と飞分類し得たが，両者とも支配神経線維が 極めて䄉細で，この 2 者を上皮内自由神経終末の如く，1つは有䯣神経終末であ り，1つは無髄神経に由来するものであると分つことは出米なかった．

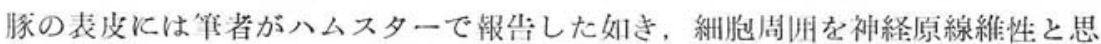




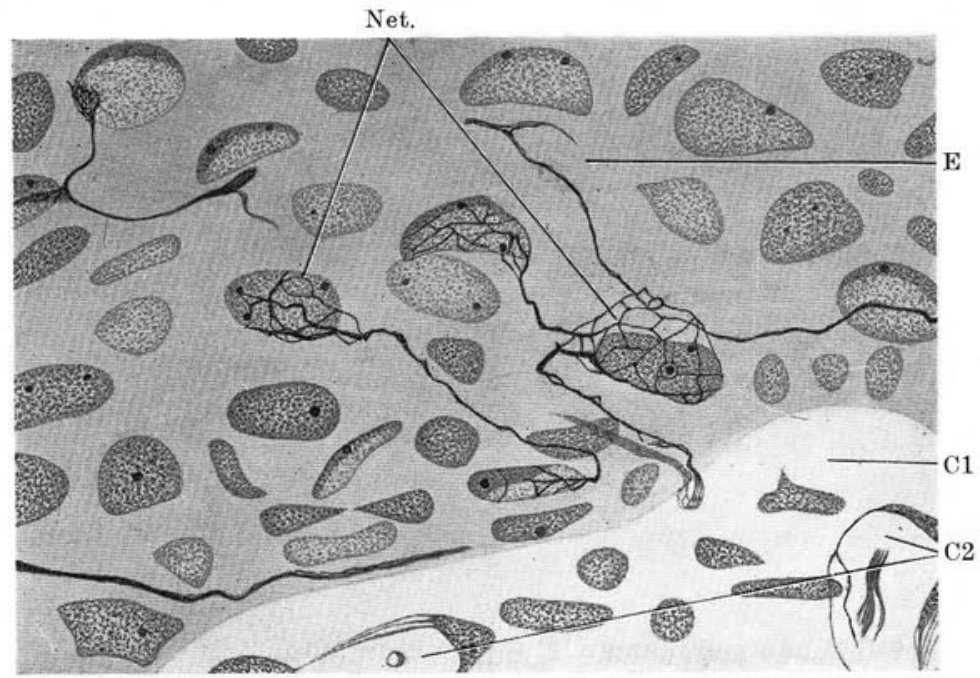

Fig. 6. The second type of tactile cell of IMAKO-SUZUKI in the epidermis. Net network of neurofibrils, $E$ epidermis, $C 1$ corium, $C 2$ cross section through end-bulbs.

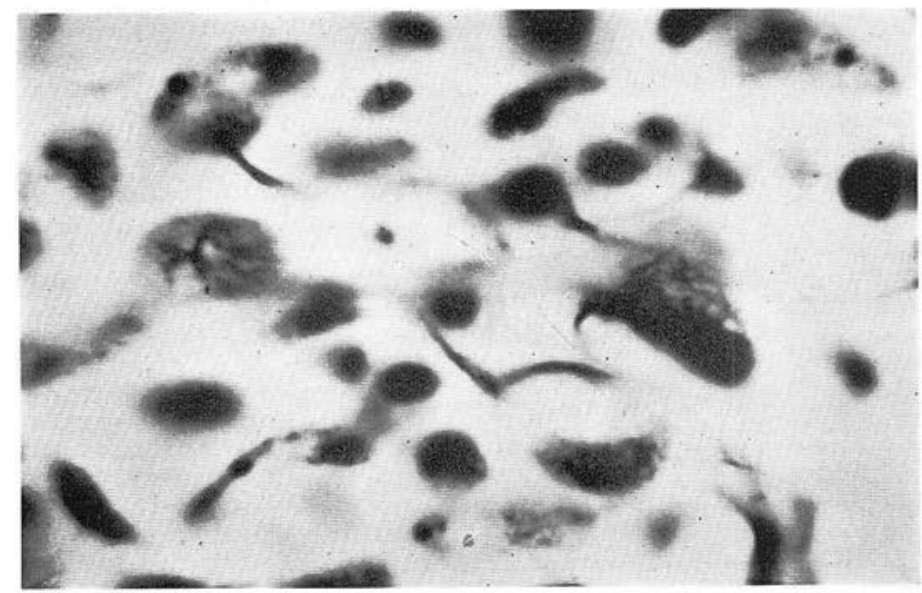

Fig. 7. Photomicrograph of Fig. $6 . \times 2,000$

われる䄉紐な網目がとりまいた特永な感営細胞は認められなかった.
B. 点
皮。

前述したようと点皮の乳䫏横造は非常によく発達している。怔物に於てとりわ

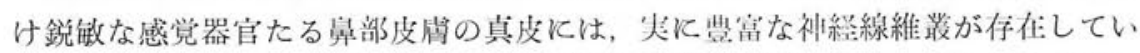
る.この真皮には 1 種類の被償怡:知営神経終末器官が現われる. 豚の鼻皮ではこ

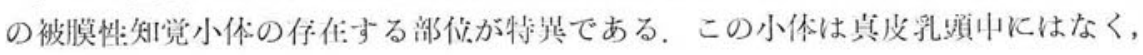


Epithelzäpfchen 基底部直下の真皮中飞ある. 尚真皮内触覚細胞（coriale Tastzellen）の存在は認められなかった.

1. 終末根 (図 8 と 9 ).

真皮の有髄神経線維中のあるものは, Epithelzäpfchen 直下飞棍状終末小体に 属する1種類の被膜性知覚神経終末器官をつくって終る.

この場合に1本ないし極く少数の有髄神経の先端が, 棍状終末になって終る全 く単純な形から，有䯣神経線維束の先端の各々が棍状終末となり，その全体を結 合織性被膜が被い, 内部で带状終末線維が分枝, 捻転或いは迁曲する為, 非常に 複雑な形をつくることがある。この複雑な型の形態を明らかとする為には, 連続 切片による復構技術 (Rekonstruktionstechnik) が必須である. 復構による複雑型 の解明は一応今後の課題とし, 今回は概ね一般的な単純な型をとりあげそれにつ いての記載を行 5.

この終末棍は一般の真皮内知覚神経終末器官と同じくその最外層に被膜を有し ている. この被膜は $2-3$ 層の層板からなり, その層板の処々には扁平な核が存 在する.

この被膜の内部には, 外棍 (äusserer Kolben) 内棍 (innerer Kolben) の別があり, その内棍部には有髄神経が入って带状にのびて所謂終棍 (Endkolben) をつくって 終っている，この带状にのびた終末線維は神経原線維がかなり密な排列をとって

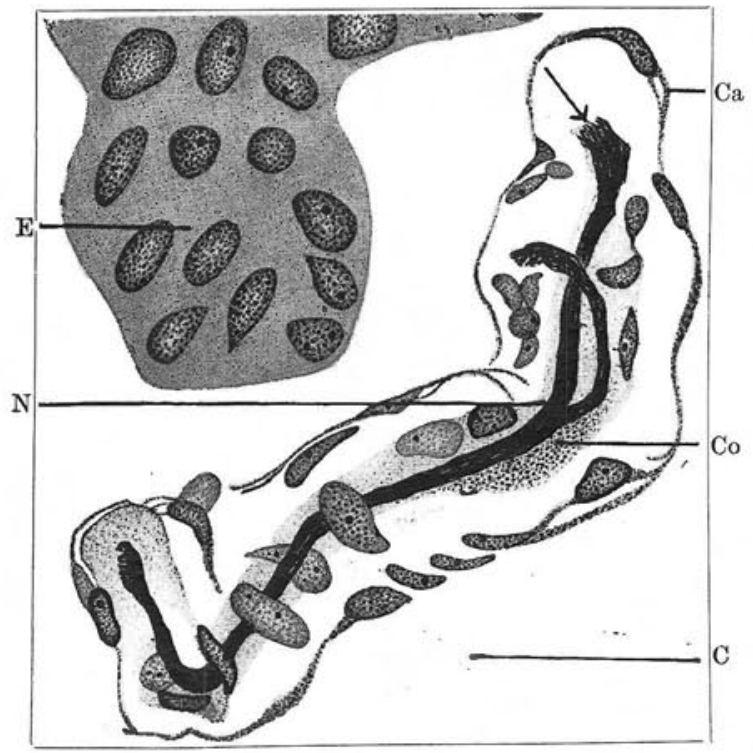

a

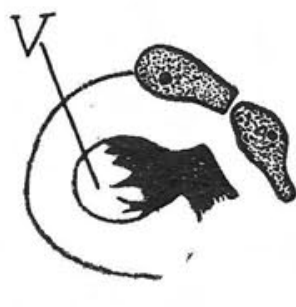

b

Fig. 8. a Longitudinal section through a typical club-like end-bulb in the corium. The arrow does not indicate the terminal enlargement. This terminal expansion with vacuole is shown in b. $E$ epidermis, $C a$ capsule of connective tissue, $N$ bandlike nerveending, $C o$ core, $C$ corium, $V$ vacuole. 


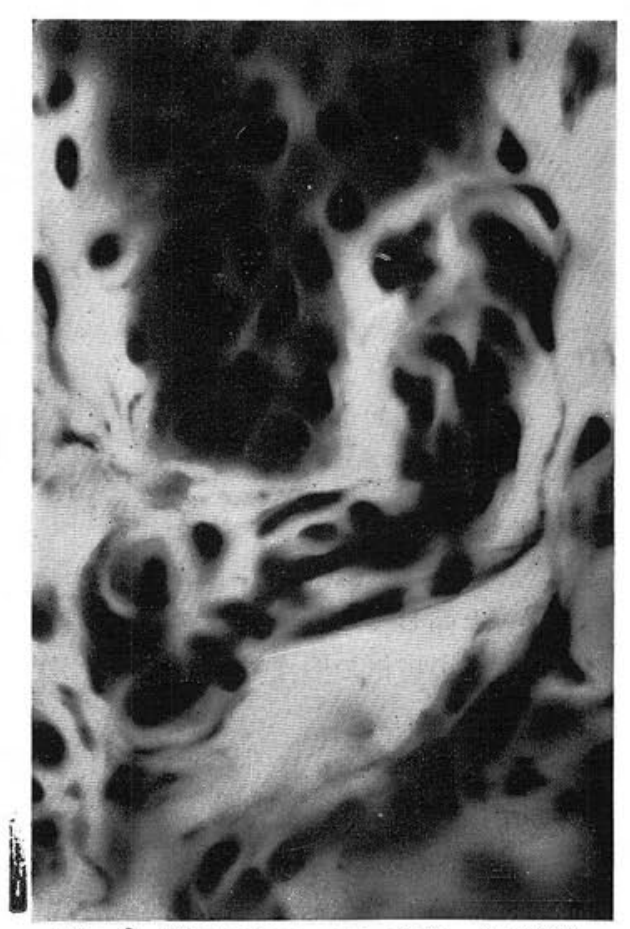

Fig. 9. Photomicrograph of Fig. 8. $\times 690$.

いる場合と, 非常飞疎になってい ることがある，その先端はやや膨 隆して終っている. その膨らんだ 先端は空胞状を呈して終っている ことが多い(図 $8 b$ と 10). 而し乍 ら中とは空胞化せず, 神経原線維 構造が単に疎になってその膨らみ をつくっている場合もある.

この棍状終末小体では带状終末 線維は二叉注分岐することはある が, 带状線維のみが多くの係踥 (Schlinge) をつくったり, 系毯状 を呈したりすることはない，但し 終末線維がその被膜と共飞捻枟或 いは迁曲して, 丁度飴の棒を強く 㨝ったようとなり，かなり複雑な 外観を呈している場合もある。

带状終末線維の周囲で内棍部と 外棍部の境目飞も薄い層板が認め られることがある。 この内層板に も処々核が存在する.

被膜と内層板との間, 即ち外根部には Vater-Pacini 小体や Timofeew 小体の如 き多数の層板構造はなく, 非常飞明るい無粠造の物質でるたされている. 而し乍 ら内棍部に属する内層板と带状終末線維との間はやや特異である。この場所には, 極めて淡く銀飞染った線条或いは顆粒（図 8a, Co) が存在する。この5すい好銀 性の顆䊀又は線条が带状終末線維の神経原線維に関係するものであり, 神経原線 維が次第に細く淡くなって周囲の領質 (core) 飞移行していっているのか, 或い

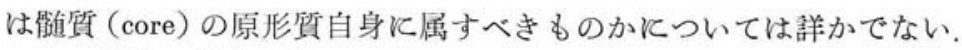

この带状の終末線維が細い無䫻線維を伴っている場合もあるが, かかる例は多 くの標本のうちごく僅かとしか認められなかった。終末線維の周囲をこの無蝺線 維に由来する終末網或いは Timofeew の糸状装置 (Fadenapparat) がとりまいて いるといらことはなく, 内㬝板と終末線維との間の淡い好銀性の線条が, 無䯣神 経線維に山来するものであるとは全く考えられない。

2. Eimer の器官.

上飞述べた表皮と真皮の知営神経終末を綜合してみると, 表皮には上皮内自由

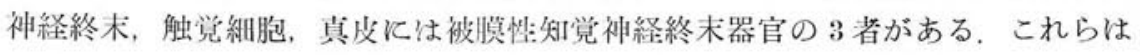
モグラの Eimer の器官を構成する, 神経関係した 3 構成要素である. 而し豚曾 

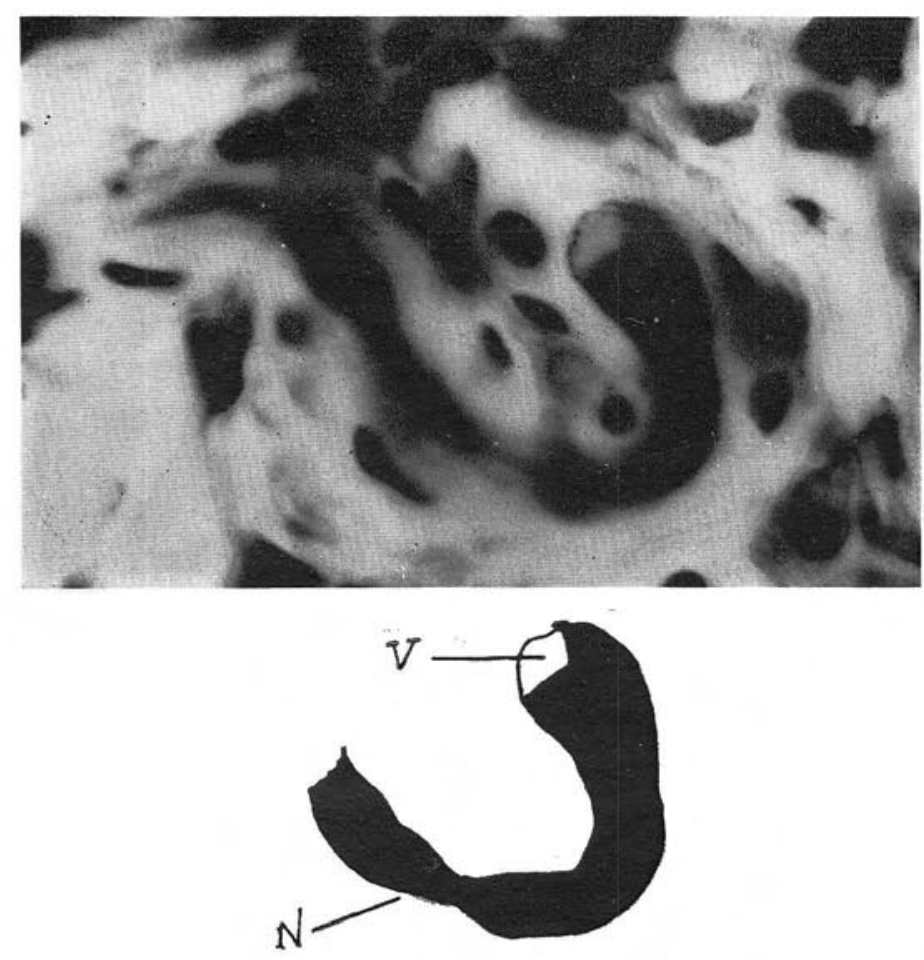

Fig. 10. A club-like end-bulb in a longitudinal secton, showing a terminal enlargement of the axial nerve fiber with vacuole. $V$ vacuole, $N$ axial nerve fiber. $\times 1,100$

皮に於てはその 3 者の排列がモグラの如く規則正しくなく, 全く互いに遊離しあ っている.

\section{C. 触 毛.}

篚者が標本を作製した部位の豚郻皮では，触毛（洞毛）以外の毛は認められな かった.

材料と研究方法の章で述べたが, 今回は材料の関係上環流固定法は施行し得な

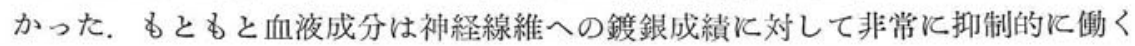
が，毛根部をとりまく大きな毛細血管洞を有する触毛とこの環流固定法を行い得 なかったことは, 触毛への神経支配の微細榄造を充分に論ずるには些か物足りな い結果となったのは当然である.

而し乍ら観察し得た籁囲ではその神経支配の形式は, ほぼハムスターのそれと 同じものと思われる.

ただ異なっているのは, 直上性終末線維と環状線維とが, ハムスターでは別筬 そ存在していたが，豚では皮脂腺下飞画省が融合しあっている，即ち毛包底部に 
達した有能神経線維束は, 毛包内を毛根とそって上行し, 次第と両鞘を失い乍ら 皮脂腺の下に達して, 一部は毛の縦軸に平行に, 疎らな神経原線維性のふくらみ を作って終り, 又他の一部は横走して毛を環状にとりまいている。この両者の線 維は処々で互いと吻合しあって, 籠状の小神経丵をつくっている (図 11).

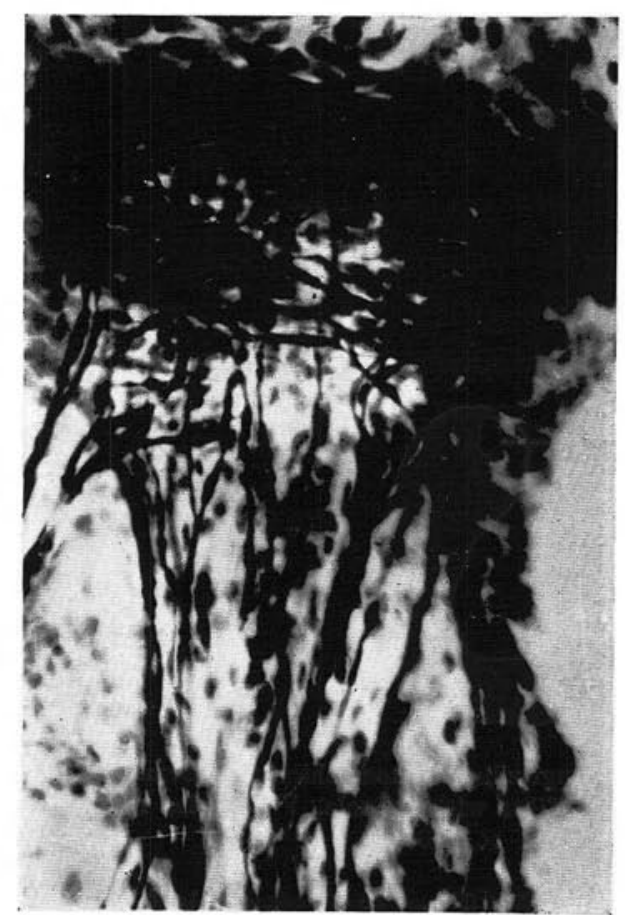

Fig. 11. Longitudinal section through the dermic follicle of a tactile hair with the rectilineal and circular forms of the myelinated nerve fibers. They fuse to each other to form a basket-like plexus. $\times 300$

これらの線維から更と終末線維 が硝子膜を貫いて外根鞘の最外層 そ達し, 多数の触営盤をつくって 終っている. それ故外根鞘最外層 は触覚細胞の集団でとりかこまれ ている.

触毛と抹ける皮脂腺の発達は極 度飞弱く, 皮脂腺内部飞も又毛乳 頭部にも神経終末線維は認められ なかった。

表皮が毛の上皮性毛包飞移行す る一方の側で, これまで毛小板 (Haarscheibe) として知られてい る場所では, 神経終末器官として

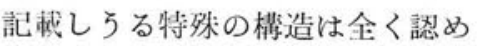
られなかった, 又との直下の真皮 内部飞真皮内触営細胞 (coriale Tastzellen）が推樍して存在して いるということるなかった.

\section{III. 考 察.}

a)上皮内自由神経終末. 篗者のハムスター鼻皮での論文 （今子 1958）で述へたようと，これまで組織学的観点より最も問題となり大きな 論争を起したのは, 上皮内自由神経終末と上皮細胞との関係である. 即ち上皮細 胞間飞あって交配しているのか, 上皮細胞原形質内部飞あって支配しているのか ということであった (Pinkus 1927, Boeke 1931). 大多数の学者一Botezat, Cajal, Tello, Dogiel, Trejakoff, Kadanoff そょって紐胞間存在説が庄倒的飞支持されて きた (Boeke 1931).

とりわけ Kadanoff は牛の幕皮の研究で, 彼の有名な図 (Kadanoff 1924, S. 434, Abb. 1) と共飞細胞間存在は絶対飞確実であるとした。 而し Kadanoff るとの後 1928 年の研究では彼の意見を少し変え, 細胞内部を通って原形質内部飞終るもの も一部にはあることを認めた (Boeke 1931). 
Boeke (1931) は1925年種々の上皮で，知覚神経小釦状終末 (end-knobs) む上皮 内神経線維も原形質内部飞存在することを観察した。 又 Jaburek 1927 年蛇の 皮散の上皮細胞内部に存在する珍らしい終末球（end bulb）を記載した（Boeke 1931).

以上の如く上皮内自由神経終末上上皮細胞との関係には 2 説があって, Boeke の高を偕りて言えば，この問題は未だ決定的には解決されていないのである (Boeke 1931. P. 278).

又最近では上皮内神経線維ならびルその上皮内小釗様神経終末は，一部は絧胞 内部にあり一部は細胞間にありとする，两者を折挔した意見を出している学者も ある(Stöhr 1951, S. 216).

今日にいたるまで以上 2 説があって確定され得なかったのには多くの理由があ ゲられる、その第1の根底をなしたのは主に組織学的見地からの問題であった。

神経組織に属すべき神経細胞の突起が, 全く暴った組織に属する上皮細胞内部に

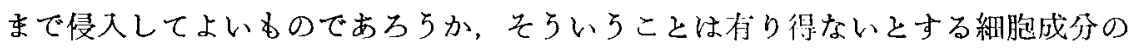
独立性なる古い慨念 (brick-theory) (Boeke 1981，P. 244) が支配的であった為で ある。

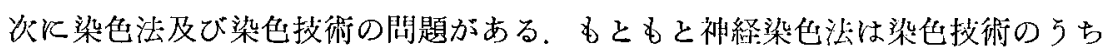
で最も難しいものであり，上皮内自由神経終末の最先端にいたるまで管全に染め 出すことは奏に至難な業であった，加えて上皮内神経と上皮細胞との関係を観る にな，神経線維が染っているのみならず，上皮細胞原形質も充分に染っていて， 上皮細胞間と上皮細胞質との区別を良くつけられるような標本でなくてはならな W.

この高度な染色技術と，優秀な染色法の献求されることが，その決定を阻む 1 つの大きな原因でああった。

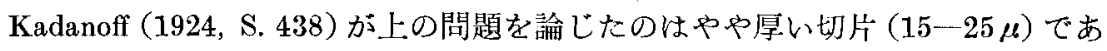
った. Boeke (1931，P. 278) は極めて薄く $(3 \mu)$, 入念作った切片について行っ た.とりわけ Boeke (1931，P. 282) は薄い切片（3-5 ん）で観祭しなければならな いということを非常に強調している。

勿論細胞原形質内位置を論ずると当っては，先ず出来る限り大きな細胞をもつ 動物を用いて，薄い切片で行うにこしたことはない，而し乍らその論拠の最大の 根幹をなすのは，上皮内神経線維をその末端の小釗状終末にいたるまで完全に染

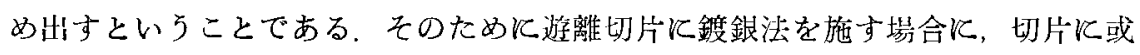
る程度の厚さ $(20-30 \mu)$ が必須となることは経験者の等しく認めるところであ る、標本さ克完全に染め上っているならば，この程度の厚さが観察の奶げをなす ということは，全く無いのである.

筆者がこの問題を論じた標本（図１と２）は，大きな上皮細胞をすつ豚を材料 として，上皮細胞原形質が茶褐巴比余す斦なく染り，細胞間隙は劃然と白く残り， 
上皮内自由神経はその小釗状終末にいたるまで䇥全に染って，污い銀粒子の沈測

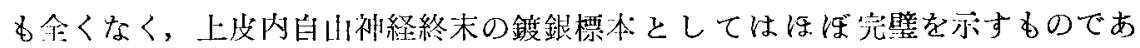
万.

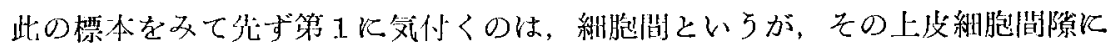
果してどれ程の余地（space）があるかといらことである，その間隙たるや立体的 な上皮細胞が上下去右重なりあって，その間に出来た全く不規則な尖に狭い境目 を示しているとすぎい。

この棈めて狭い又全く不規則な間隙内を，上皮内に入った神経線維が特に選ん で走るといらことはどうしても考えられないのである。篗者がこの標本をみた時， 又他の多くの標本を，むし上皮細胞原形質が染っていなければAzan 或いは Eosin をかけてその境界を明らかにして観祭した時, 上皮内自由神経線維は完全飞細胞 内部を通過して和り，その小釗状終末も細胞内部飞存在しているのである。

もし最も箃密に述べるならば, 上皮細胞内部に大って, 一旦僅かの間, 間隙に 出て又次の細胞に入り，これを繰这し乍ら肧芽層最上層飞達して小剣状終末を上 皮細胞内部に形成して終っているといらことになる。

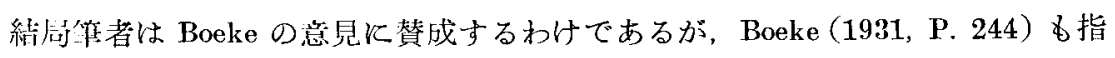

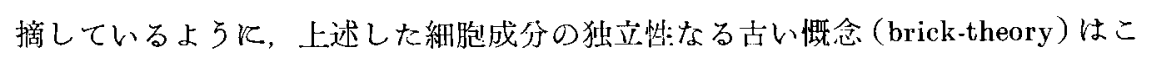
の際充分飞批判検討されなければならない。

尚此の問題は単飞上支細胞と上皮内自由神経終末との関係飞止まるものでな く，全神経終末と Erfolgsorganの細胞が此の立場から考光られなくてはならない といらことを示唆している。

Kadanoff（1924）は上皮内自由神䌊線維を，やや太い第1杼と之に比へてかな り細い第 2 稙の線維と飞分ち，Pinkus（1927）も神経の終っている皮膚の出んな 埸斦が，やや太い主線維 (Hauptfasern) と細い副線維 (Nebenfasern) の活者によ って支配されていると云っている．Boeke (1931，1934）も亦モグラ舅皮の Eimer の器官に於て，上皮柱内に1本の太い主線維があり，更にこれるとり囲んで多く の細い辺縁線維が存在することを認めている。

豚の表皮飞於ても上皮内自由神䌡線維に明らかにこの雨者が存在する.

表皮内に侵大した 1 本の主線維の周り飞萿干のかなり細い線維が認められ，相 並んで其质表皮内を迁路曲折し作ら上行している。雨者はかなり近接しあってい るが，殆んど接触或いは吻合を亦すことはなく，ただ稀に副線維が主線維と連絡 しているのを認めることがある。

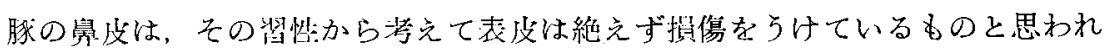

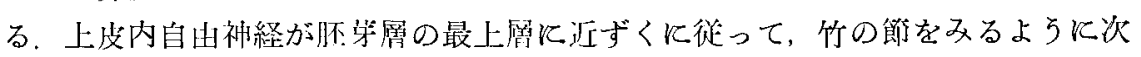
々と小剑 (Knöpfchen), 静脈㿔様膨隆 (Varicositäten, end-knobs)をつくっている が、このことは絶えざる表皮表厤の損傷脱落に対応して, 神経線維も亦再生能力 のあることを亦しているるのと㘷えられる，絶えざる表皮表面の細胞の損失に対 
して，永久的な表皮自身の新生と改築活動飞件って，上皮内神経子亦少からぬ再 生能力（Regenerationskraft）を队在すべきだとは，Stöhr (1951，S. 216) も述べて いるところである.

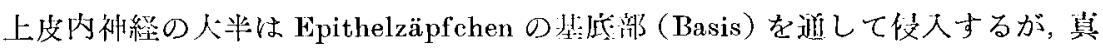

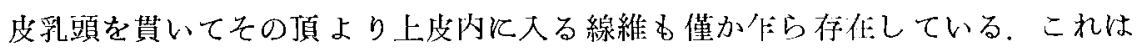
Kadanoff (1924)の牛の鼻皮での所見と同じである。

b) 触覚細胞.

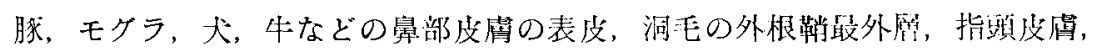

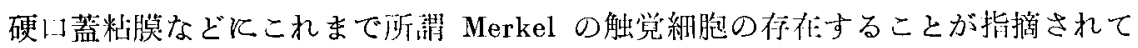
いる.

篗者はハムスター鼻皮の洞毛外概鞘に於て, 今日まで Merkel の触覚細胞とし て考えられているむのに2つの型のあることを明らかにし，その微細な形態学を のベ，これに詳細な考察を施した（今子1958）。

次いで今回豚鼻皮を研究するに及九で，同じく Merkel の触覚細胞を2つの型 に分類することが出来た，その2つの型の形態学は八ムスター鼻皮外根鞘に於け るとれと金く同様であった，その各々と今子一鈴林の触営細胞第工型，今子-鈴木 の触喾細胞第I型と命名した(図3，4，6，7).

今日までの触筧細胞の形態学を㛗約してみると, それは非常に朋るい細胞であ り，かなりの範囲をるったやや扁平な核が特徴的で, 原形質の結合組織飞面した 側飞, 神経原線維性網状の触覚盤 (Tastmeniskus, Tastscheibe)を有つことが知ら れている(Stöhr 1951). 更に Boeke（1931）はこの触筧盤から周終末網（periterminales Netzwerk) が出て原形質と連絡しあっていることを観祭した、就中こ れまで非常に問題となったのが触覚盤の位置であった。人抵の学者によって触覚 盤は触覚細胞の下方に貼りついた，所謂細胞外のもの (extrazelluläres Organ) と して見做されてきたが, Boeke (1931，P.281) がモグラの Eimer の器官を研究し て，触覚盤は触覚細胞飞属しその内部に存在することを明らかにした。

結局常に論議されてきたのは筆者の触覚細胞第 I 型の力であった。第 I 型に於 て触覚盤が扁平な核の下方に接して触覚細胞内部にあることには全く問題はな い. 神経原線維盤の下方源はBoeke (1931，P. 281；1934，S. 862) の云う如く，企 く5すい1㬝の原北質しか存在しないのではなく，触覚細胞のほぼ半分を占める 程の空胞が認められるのである，前飞述べたが，触覚細胞が非常に明るく兒える のる此の為である。触覚艋から出た更飞微絒な原線維はこの望胞と関係し，この 空胞をとり用んでいる，そして扁斗な核或いは空胞以外の他の原形質との関係は 認められないのである。

もしも Boeke がモグラの鼻皮 Eimer の器官に於て, 䈆者の第II型の方を観察 したとすると、この第林型の方には触覚盤として持飞抬摘しらるようなおのはな いのである、モグラ Eimer の器官についての踰木, 推者の研究があるが, 後飞 
報告する予定である.第II型の核をとりまいた網目は真に緎細なるのではあるが， 支配神経線維との連絡は充分に観祭出来.る。豚鼻皮に於てはこの第II型は第 I 型 に比較して極めて少く, この第II型の方の形態をもって, 全ての触覚紐胞の形を 律するわけにはいかない.

若干の触覚細胞が同じ神経線維の終末枝によって支配され，明確な集合体を形 らくるとは Dogiel（Boeke 1931）あ述べているところである，その支配形式をみ ると前述した如く，上皮内に入った神経線維から若干の枝が出て，その枝の先端 の各々が触覚盤をつくって終っているのではなく、微細な神経線維が触覚細胞内 部に入って触敩盤をつくり，その触鸴盤から更飞枝が出て再び触覚盤を形成して いるのである，即も端的に至って触覚細胞は神経線維によって数珠つなぎとなっ ている、そして乳頭と乳頭とにはさまれた上皮の基底部に於て明確な集合体を形 成しているのである。この神経支配の様式は，八ムス夕一触毛の外根鞘最外層に 拉ける触覚細胞の場合も同様であった.

人及び二三の哺乳動物に於てみられる Meissner 小体の最る単純な形がこの触

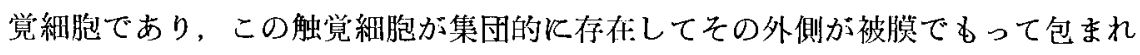
たのが，Meissner 小体ではないかと推察されるが，この小体内部の神経線維の走 行もこの数珠つなぎ形式をとっているるのと考えられる。

この数珠つなぎ形式はとりわけ哺乳動物に特徵的であり，鳥類殊に水禽の蜳皮 (Wachshaut)飞みられることの多いGrandry 小体飞於ては，又異った支配様式を とっているのではないかと想像される。

今仮に神経線維を撃線とし触覚細胞自身を電池と晃做した時，この数珠つなぎ の形式は亚列でなく直列式であるよ5に考劣られ，興味深いるのがある（図 5 ）。

Kadanoff (1924，S. 450) は上皮内自由神経の小釗様示くらみ或いは小鈿状終末 をもって, 触覚細胞の触覚盤に相当するるのであるとみなし, Boeke (1934, S. 861) も亦触覚細胞は上皮細胞と小钏状終末との間の関係が更に複雑化したものとの見 解をとっているが，雨者が共に数珠つなぎ形成をとっていることは相似た点であ る.

Pinkus (1927， S. 356)，そして Boeke (1934，S. 862) も真皮内触営細胞（corjale Tastzellen）の存在を指摘しているが，豚と於ては Epithelzäpfchen 基底部飞存在 している触覚細胞集団は明らかに表皮に属しているるのであり, coriale Tastzellen の存在は認められなかった。

3. 終末棍.

豚舅皮の真皮に現れる知覚神経終末器官は，この棍状終末小体のみであるが， 前述した如く豚鼻皮にてはこの小体の現われる場所が特異である. 即ち Epithelzäpfchen 直下の真皮で，触覚細胞の集団と相対した場所である。これは Boeke (1931，P. 283, Fig. 8) がモグラ鼻皮のEimer の器官の研究で, その構成分子の 1 つとして認めた層板小体（Lamellenkörperchen）の位䐈と同じである. 
豚鼻皮に於て，真皮乳頭は非常によく発遵しているのであるが，この真皮乳頭 内部に知党神経終末装置は認められない, 徒って豚鼻皮に於て特飞神経乳䫓 (Nervenpapille)，血管乳頭 (Gefässpapille) の区別はつけ難い.

結合組織中に在る被膜性知覚神経終末器官については，これまで数多くのもの が報告され，それぞれの発見者の名前がつけられて，その形態学すかなり微細な 点にまで及んでいる。

筆者がこの豚鼻皮真皮内でみとめた被膜性:終末小体は, Timofeewによって，犬 の前立腺外結合織鞘，猫の尿道前立腺部粘膜その他でみつけられ，1896 年別棰の 被膜性神経終末として報告された，所謂 Timofeew 小体にやや類似している.

而し筆者の終末小体は被膜はうすくせいぜい 2-3層であり，外棍部 (äusserer Kolben）は全く無構造の物質であり，Pacini 小体或いは Timofeew 小体の如き多 数の層板構造は認められない（図 8 と 9). 又 Boeke (1931，P. 281) がモグラの Eimer の器官で認めたのは, 簢単な構造の Pacini 小体及び余り複雑でない Ruffini 小体の性質をもったものと記載している.

な拉 Timofeew の小体と非常飞烡った点がある，彼は内棍部に於て，带状飞終 る太い主線維とは別に細い神経線維が侵入して，带状の太い終末線維の周囲をと りまく微細な網目をつくっていると述べている。彼はこの継状構造を Fadenapparat (Timofeew, 1896, S. 45) と名づけた. そして一般的には Timofeew の装置 (Timofeewsche Apparat) として知られている (Stöhr 1951, S. 219).

Stöhr む亦人の軟脳膜に於て，Krause の終棍に似た知覚性終末系䟵 (sensibler Endknäuel) 内でこの終末網を記載している(Stöhr 1951, Abb. 212).

これまで知覚性終末器官に於て太い終末線維と共に小体に入る無鹃線維の存在 がかなり報告されて怙り，Boeke (1931) の如きは終末小体の組織学に於てこの無 髅神経線維の記述がなかったならば完璧でないとまで言っている.

而し前述したようK，筆者が多数の標本で入念飞観察した範井では，無髄神経 の存在を確認することは出来なかった.

そして内棍に於て带状終末線維をとりまくという西謂 Timofeew の Apparat は全く認められなかった。

Timofeew (1896, S. 46) は更に币広い带状終末線維が内棍の中軸に横たわって いるのに, 彼の periaxiale Fadenapparat は内棍壁に直接境を接しているよ5に観 えると述ベている.

筆者の観察では, この内棍壁にあたる部, 即ち内棍部と外棍部との境には尚薄 い好銀性の層板があって，その境界をつくっているように思われるのである，被 膜に於て認められるとほぼ同様なレンズ状核及び卵円形核がこの境界にあたる部 にも並んでいるのが観察される。

Timofeew の行ったのが Methylenblau 染色であり, 篰者の施したのが神経線維 染色法としてより精密なBielschowsky の鈴木氏変法であることを思う時，この差 
異の生じた点が何か染色法の違いにあるように考えられる。

今日までの带状終末線維自身の記載については，内棍中州で裸の軸索が川公く 平坦且つ带状となって鋸料状の辺縁をすち，去の先端は常に柾らな神経原線維性 のふくらみをるって終るという人体一致した記載である（Timofeew 1865, Boeke 1931).

又 Stöhr (1951，S. 218) の如く先端の疎になった神経原線維怡のひろがりは，鍍 銀法で dunkel rosa そ染るTerminalplasmaに終っていると述べている学者すある.

な拴ての求心性，邀心性神経終末がそうであるように，この耑状終末線維の 先端も，避雷針の尖端（Blitzableiterspitze）の如くに尖鋭状にと切れて終ってい ない(Stöhr 1951, S. 215).

処が，非常に立派に染っていると充分自負するにたり，垁に慎重に作製した標 本について篗者が入念飞観祭していった結果，この带状終末線維でこれまでの慨 念と少しく異ったものをみた，即ち带状終末線維の先端の神経原線維性のひろが りは空胞状になって終っていることが多く，又空胞化せず，単に神経原線維性の 疎らな広がりにすぎないこともあった。

この先端の空胞構造についてであるが，上述してきた知覚神経終末の構造をみ た時，その先端の神経原線維性の広がりと空胞化とい5のは垁に密接な関係をも っているようである。筆者が観察した上皮内自由神経の小釦状終末は小空胞状で

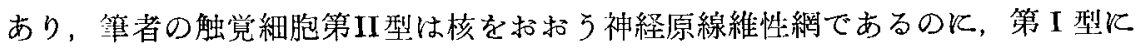
於て神経原線維性の触覚盤はかなり大きな空胞を抱いている。このような点から 推して，終末棍の軸索線維の先端が神経原線維性のひろがりと空胞構造をもって いても，決して不可解なことではないと思う。この空胞構造を変性像或いは人工 産物だと解釈することは却って事尘を歪曲したものであるう．

逆に求心性神経終末に於ては，この空胞構造に大なる意義がひてんでいるので はないかと考朰いる。

笰者が多数の標本について観察してみると，前述した如くその先端が空胞化し ているものが，殆んど大部分を占めていたが，中疎らな神経原線維性のひろが りに過ぎないものもあった。

此のことから更に一步を進めて，求心性神経終末の先端が神経原線維性の方く らみを持ち，それが空胞化するといった，そこに何か生理的機能に忘じた動きが あるのではなかららか.

即ち求心性神経終末に関連して動態なる重要な慨念が導入されてくるように考 えられる。神経終末飞関する今日までの定説の如く，針金のように全く湖定し七刀 ったものとは思われない，な扣此の事尖を確定するには，他の㮔々な形の知覚神 経終末器官及び他缄器の神経終末を研究し, 或いは夹騟的研究を行い,この観点 に立った多くの観察を施していかなくてはならない。

結合緗織内部飞現われる知覚神経終末装置に於て，その厚薄の差こそあれ全て 
に共通な被膜の性質については, 結合組織㤬のものであり, 噖原線維と弾力線維 とからなるといらのが今日の定説のようである（Boeke 1931，Stöhr 1951）。 又 Pacini 小体飞於て，その被膜及び多くの蟹板は Henle 鞘に一致したものであり， 内棍は変形した Schwann 鞘を表わしていると将えられると述へている学者もあ る (Takashi, Sakai, Ushizima 1955, P.18).

筆者もこの豚舅皮真皮に括ける被膛性終末小体を観察して, 被膜, 外棍, 内棍， 内棍内の終末線維, 内棍と外棍の境と思われる䇢処飞あるうすい層板を区別し得 たが，これらの処見を綜合してみると，矢張り上述したTakashi とほぼ同一意見 となる。被脱は Henle 鞘であり，内棍は髉鞘の延屒であり，内根壁の層板は丁度 Schwann 鞘飞あたり，外棍と内棍との間の無構造の場门は淋巴脂飞一致するもの ではないかと茢えられる。

この被膜㨫小体の外棍にあたる部に，多くの層板が形成されたのがPacini 小体 と考古られ，被膜はそのままで带状終末線維のみが数多くの係瑞形成 (Schlingenbilung), 或いは糸求体形成 (Knäuelbildung) を行ったのがKranseの終棍系と考 えられる。結局この被膜㤬小体の単純な形が基礎型となって，これから更に複雑 な知覚神経終末装置へと分化していくのであるう。

な括此の終末小体と，ほ臣類似の構造を持っていると思われる特殊終末棍 が, 山羊舌背, 舌下面, 舌後部の夫々固有朕内及び舌乳䫓内でも認められている (Yamamoto 等 $1957 \mathrm{a}, \mathrm{b}, \mathrm{c}$ ).

d) Eimer の器官.

非常に剌戟飞敏感な場処で，個々の終末装置が規則让しく排列され，それらが 統合されて1つの特殊な終末器官をつくっている。 その終末器官す亦規則正しく 相亚んでいる。このような例の1つが1871年 Eimer によってモグラの舅皮でみ つけられ，彼の名をとって Eimer の器官と名づけられた.

欧州産モグラに於计るEimer の器管に関する真に精細な研究が, Boeke (1931, 1934)によってなされた。

彼によれば，モグラの鼻部表面に小さな球状の隆起がみとめられ，その場処に 一致して重層扁平上皮の肥厚があり，上皮細胞が変化して円筒形の柱（Epithelsäule）をつくっている，その上皮柱の軸飞，1本の太い中心線維が走り，上皮柱 の辺縁に15-20本の所嵲辺䋹線維が上行している.上皮柱の基低部, 即ち Epithelzäpfchen 飞 4-5 值の触覚細胞があり，Epithelzäpfchen 飞対する真皮の部に1一 3 個の曆板小体が存在している（Boeke 1931, 1934).

結局 Boeke汇よると, Eimer の器官は上皮柱内を走る上皮内自由种経終末, 触 覚細胞，層板小体，この3 者飞よって構成されていることになる.

その各々についての考察を順次述べてきたのであるが，豚舅皮に於ても明らか にその 3 要素を具備している，而し乍らその排列が真皮乳頭と乳頭とにはさまれ た各表皮毎に全く規則正しいとは至い難い。又上皮柱なる上皮の特別の変化もな 
く，鼻皮表面特有な粒々の隆起もない。だがその3 要素を有していることは事 奏であり，豚鼻皮は Eimer の器官の各構成要素が夫々散在的に自由な排列をと ったものであると㕕い得る，又豚鼻皮なる特別に発達した感覚部位は，その知党 神経終末装置として Eimer の器官の各構成要素と触毛とからなっていると云ら ことも出来る.

e) 周終末網 (periterminales Netzwerk).

骨格筋飞於て逗心性神経線維が終る運動性終板 (motorische Endplatte) 内部で, 1909 （1911）年 Boeke（1931）は神経原線維と明らかに連絡している非常に微細な 網目の存在を記載し，周終末網 (periterminales Netzwerk) と命名した。

彼によれば，この周終末網こそ神経刺戟伝導に最む大きな役割を果しているる のであり，神経終末と終末器官との原形質性つながりを，この周終末網が果して いると述べている。

運動性終板の靴底質 (Sohlenplasma) 中に存在する周終末網については, 当教 字の鈴木 $(1958)$, 田中 (1958) の優秀な業蹟があり，その研究は更に微紐な点に 及び，周終末網と筋原線維との関係へと進んでいる。

鈴木，田中の素晴しい標本をみては，連動性終板内部に和ける周終末網の存在 について，全く疑問の余地がなく，終板内部の周終末網の存在を第 2 義的（von untergeordneter Bedeutung) の問題であるとした Stöhr (1951, S. 223) の意見は些 か軽卒の嫌いがある。

而し乍らここで問題のあるのは, Boeke がこの周終末網を運動性神経終末のみ ならす数糧の知覚神経終末器官飞於ても認め,この周終末網なる慨念を運動性及 び知覚性の両終末器官に共通した事尘であると見做した点である（Boeke 1931, 1934).

彼はモグラの触覚細胞に於てこの周終末網をみとめ, 更に Grandry 小体で観察 した.

筆者はハムスター触毛外根鞘及び豚鼻皮で, 触覚細胞についての精細な研究を 施し，その詳細な形態学はこれまで述べてきた通りである。

今子一鈴木の触覚細胞第I型に於て，触覚細胞の核をとりまく微細な網目は Boeke の云う周終末網と非常によく類似しているが，触覚細胞はこの型のみでは ない，触覚細胞中にはな挌多くの数を占める第 I 型がある。この第 I 型では触覚 盤より出た繊細な原線維様構造, 或いは網目は, 触覚細胞内部にある空胞に関係 していてこれを取巻いているのである.

豚表皮の上皮内自由神経終末に於ても，上皮細胞内部にある小釦状終末と上皮 細胞原形質と連絡するような周終末構造は認められない，筆者の観察した標本で は，小釦状終末は神経原線維網ではなくて，小空胞状であった。

真皮に括ける被膜性終末装置の带状終末線維に於ては, 带状線維の周囲, 換言 して内棍部の髄質（core）にあたる処に非常に5すい好銀性の線条，或いは顆粒 
が認められることがある，前に述べたが，このるのが終末線維に関係しているの か，髄質自身淿属しているのか詳かでない。

而し乍らその葉状にひろがって疎らになった神経原線維の先端をみた時，その ままのことああるが，円形の空胞に終っていることが多い，

このようと数種の知覚神経終末器官を観察してきた時, 先ず第 1 亿問題になる のは周終末網ではなく，求心性終末の先端が形づくる空胞である.

この空胞をみたす化学的物質は一体何であるのか，神経刺戟伝導にその物質が いかなる役割を果しているか，今後の神経終末の組織学に大きな疑問を与えてい る.

結局知覚神経終末装置に於ては，Boeke の唱える周終末縌よりもこの空胞構造 に大きな意義がひてんでいるように思われるのである。

更に神経原線維性ひろがりとこの空胞構造に何等かの関連があるようであり， この点にも今後充分着目していかなくてはならない.

\section{IV. 結铻。}

成熟した豚鼻皮で約 $30 \mu$ の凍結切片をつくり，これと鈴木清氏鍍銀法を行い， その知覚神経終末の超激細構造を得て, 極力 Erfolgsorganの細胞との関係を追求 して得た結果は次の通りである。

1. 表皮の上皮内自由神経終末には 2 棈類がある。即ち主線維と副線維とであ る。主線維は肧芽層の最上層に達して，小空胞状の小釗状終末をるって終る，主 線維も副線維も共飞上皮細胞間のみならず上皮細胞内部を嘪通し，小釠状終末も 办上皮細胞内部に存在する。上皮内自由神絽終末に関連した上皮細胞柱は存在し ない。

2. 真皮乳䫓にはさま机た表皮の基成部に触覚細胞の集団が現われる，触覚紐 胞飞も 2 型がある。その各々を今子-鈴木の触覚細胞第 I 型, 第II型と命名する. 而著其にその神経支配の様式は数珠つなぎ形式である。

3. Epithelzäpfchen 飞面した真皮飞特殊終末䪞が認められる。このものは構 造上Krause の終棍系, 或いはPacini 小体の最も単純な形と思わ机る。带状終末 線維の先端は，神終原線維性葉状の疎らなふくらみのことるあるが, 筀胞状を呈 して終っていることが多い. Timofeew の装置は存在しない。

4. 求心性神経終末は定胞構造を有していることが多く，その空胞構造は亦神 経原線維性のひろがりと密接な関係にあるようである。两者間に，機能的变化が あるのではないかと芳えられる。

5. 表皮内の自由神経終末，触覚細胞，真皮に括ける特殊終末棍，これらを綜 合して豚鼻皮にモグラ Eimer の器官を粨成する, 求心忙神経終末に関連した 3 要素が存在する，但しその3者の排列は互い注全く不規則であり，遊離しあって いる. 
6. 触毛の神経支配の形式はほぼハムスターのそれと同じである。而し豚鼻皮 では毛包内部の直上忙終末線維と環状線維とが互いに融合しあい，籠目状の神経 線維叢るつくって皮脂腺直下に存在している.Pinkus のZ元う毛小板なる特殊の 知覚神経終末装置は観察出来なかった。

稿を終るに当り，貴重な標本の一部の貸字と校閲の労を頂いた恩師鈴木清教授に表心感

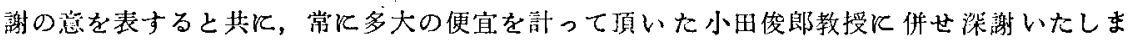
†.

\section{Author's Abstract.}

A report is made of the end-apparatuses of afferent nerves and their relations to other cells in the snout-skin of an adult pig.

Thirty $\mu$ frozen sections were impregnated by SUZUKI's modified BIELSCHOWSKY's silver-method. The results obtained are as follows :

1. In the epithelium of the snout-skin there occur two sorts of intraepithelial nerve-endings, i.e., main thick fibers which are derived from myelinated fibers and accessory thin fibers that may be primarily of an unmyelinated nature. A few accessory fibers run closely around the main fiber. The main fiber terminates at the uppermost germinal layer with small end-knobs. Both intraepithelial nerve fibers, main and accessory, pass either through the intercellular space or through the cytoplasm of epithelial cells. Knob-like endings are generally situated inside the cytoplasm of the cells forming small vacuoles, not neurofibrillar net-balls. No visualisation was made of the cylindrical columns of epithelial cells associated with intraepithelial nerve fibers, as described by BOEKE in EIMER's organ of a mole.

2. In the basal part of the epidermis between coriale papillae there occurs an aggregation of so-called MERKEL's tactile cells. Careful observations led to conclude that there might be two varieties, as reported by IMAKO, in the outer layer of the root-sheath of the tactile hair in a golden hamster. The one belongs to the first type of tactile cell after IMAKO-SUZUKI, in which a nerve fiber terminates in its cy toplasm under the flat nucleus forming a disc-like termination with a vacuole. The other constitutes the second type of tactile cell after IMAKO-SUZUKI, in which there are found neither disc nor vacuole, and the nerve fiber terminates in the cytoplasm simply forming the reticulum with fine meshes around the nucleus. It became clear on careful observations of frozen sections that the second type cells occur less than the first type cells in the pig's snout-skin. The mode of nerve innervation on tactile cells shows a close resemblance to the structure of a rosary. A branch of the nerve fiber passed through each cells to form a series of tactile cells. On its way through the cytoplasm, the nerve fiber swells to shape a knob-like termination. Unlike many author's observations on the tactile cells the present author agreed with BOEKE's observation that the so-called tactile meniscus or disc was situated inside the cytoplasm.

3. In the corium under epithelial papillae there occur a kind of corpuscular sensory end-organ. This organ belongs to a type of club-like end-bulb which shows of ten many windings and twistings. It is covered with a thin capsule of the con- 
nective tissue which is likely to be an elongated endoneural sheath of HENLE, and to be composed of two intracapsular bulbs, the dark inner one and the light outer one. Between these two bulbs there exists a thin lamelle with lenticular or oval nuclei. As this thin lamelle was assumed to be a deformed SCHWANN's sheath, the inner bulb might probably be a prolonged medullary sheath of the myelinated fiber. The outer bulb is composed of a homogeneous substance, being devoid of a lamellar structure, as seen in corpuseles of PACINI and TIMOFEEW. The band-like sensory terminal fiber runs into the axis of the inner bulb. Sometimes the terminal fiber bifurcates in the core, but its convolution and ramification are not marked. In many cases it ends at the top of the core forming a vacuole due to the enlargement of neurofibrils, but in a very few cases it terminates only with a fibrillar expansion. It never ends with a sharp spearhead appearance. In a core involving the terminal fiber, there were found small argyrophilic granules and argyrophilic striae, but no thin accessory unmyelinated fiber or 'Faden-apparat' of TIMOFEEW. In spite of careful observations an aggregation of coriale tactile cells could not be identified.

4. Generally afferent nerves often demonstrate the formation of vacuoles in their endings, e. g., intraepithelial end-knobs, first type tactile cells after IMAKOSUZUKI, and club-like end-bulbs. The vacuoles in these terminations seem to be related with a neurofibrillar expansion.

The present author's observations suggest that these parts of afferent nerveendings may have had morphological changes being subject to the changes of physiological function. But much seems still left to be seen before an established conclusion is made as to this respect.

5. The so-called EIMER's organ of a mole is composed of three elements related to afferent nerve-endings, i. e., intraepithelial nerve fibers, tactile cells, and capsulated sensory end-organs. And these three components are systematically arrayed in an epithelial papilla. A swine has also these three kinds of sensory nerve-endings in its snout-skin, but their arrangement differs greatly from that of a mole. They tend to make an incomplete EIMER's organ in one papilla, or they seem to extend over two papillae.

6. Innervation-mode of the tactile hair in the pig's snout-skin is generally similar to that of a golden hamster, as reported in the author's previous paper. But in the dermic follicle of a tactile hair in a pig rectilineal and circular fibers from myelinated nerves fuse to each other to form a basket-like plexus, above which the sebaceous gland poorly developed.

In the epidermis and corium of this animal there is found no specific form of sensory nerve-termination, such as the so-called hair-disc, which was discovered by PINKUS in human and other mammalian skins.

\section{文献.}

Boeke, J.: Cytrogy and cellular pathology of the nervous system. Vol. 1. Penfield, 1931. P. 243. - In Handbuch der vergleichenden Anatomie der Wirbertiere. Bd. 2. 1934. 
P. 855. 一今子邦男：阪书大医誌. 7 (1958). 頁 62. 一 Kadanoff, D. : Z. Anat. 73 (1924). S. 431. - Pinkus, F.: In Jadasshons Handbuch der Haut- u. Geschlechtskrankheiten. Bd. 1, Tl. 1. 1927. S. 325. - Stöhr, Ph. Jr: Lehrbuch der Histologie. 1951. 一鈴木 清: 実験治 㙩. 310 (1958). 頁 $1 ; 311$ (1958). 頁 1. 一 Takashi, M., J. Sakai and H. Usijima : Anat. Rec. 122 (1955). P. 17. 一 田中忠葓：解剖誌. 33 (1958). 頁 24. 一 Timofeew, D. : Anat. Anz, 11 (1896). S. 44. - Tret jakoff, D. : Z. wiss. Zool. 71 (1902). S. 625. - Yamamoto, T., Y. Ito, H. Ueda and J. Yamaguchi : Arch hist. jap. 13 (1957 a). P. 547. - Yamamoto, T., H. Ueda, K. Matsunaga and Y.Ito: Arch. hist. jap. 13(1957b). P. 559. -Yamamoto, T., R. Abe, T. Suzuki and S. Ohta : Arch. hist. jap. 13 (1957c). P. 596. 